\title{
The influence of connecting pile cap-column in the mechanisms of break in the two pile caps
}

\section{A influência da ligação pilar-bloco nos mecanismos de ruptura de blocos de fundação sobre duas estacas}
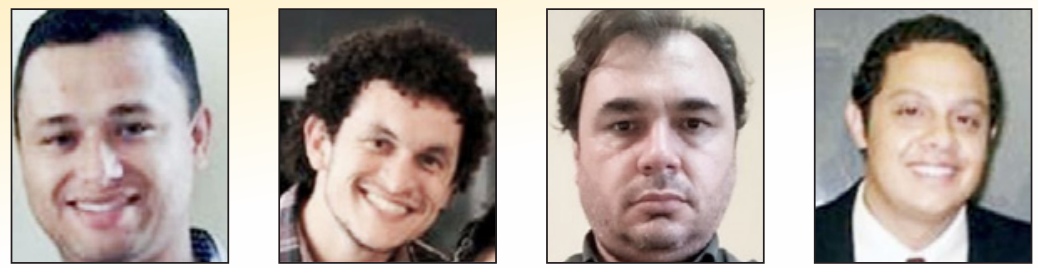

\author{
A. C. MESQUITA \\ www.srocha.eng.br \\ A. S. ROCHA a \\ www.srocha.eng.br \\ R. G. DELALIBERA \\ delalibera@ufu.br \\ W. A. DA SILVA c \\ wellington_andrade@ufg.br
}

\begin{abstract}
The paper analyzes the two pile caps with partially embedded socket and subject a center load. Three models were experimentally tested, varying the type of conformation of the column and walls of the socket, with a smooth, the other rough, and a monolithic two pile cap, used for reference. The roughening of the column-socket interface was examined with the aim of verifying the difference of the distribution of compressive and tensile stresses in the strut an tie model used for design. The experimental test to show that the two pile caps with conformation rough of the column and walls of the socket, support more load in comparison with two pile caps with smooth of the column and walls of the socket. Both however underperformed the monolithic two pile cap, with values of $66 \%$ and $36 \%$ respectively.
\end{abstract}

Keywords: two pile caps, reinforced concrete, foundations.

\section{Resumo}

O trabalho analisa o comportamento de blocos sobre duas estacas com cálice parcialmente embutido, submetidos à ação de força centrada Foram ensaiados experimentalmente três modelos, variando-se o tipo de conformação das paredes dos pilares e do cálice, sendo uma lisa, outra rugosa e um bloco monolítico, utilizado para referência. A rugosidade na interface pilar-cálice foi analisada, com o intuito de verificar a diferença das distribuições dos fluxos de tensões de compressão e tração no modelo de biela e tirante empregado no dimensionamento e, consequentemente, o comportamento estrutural. As análises experimentais constataram que o modelo com conformação rugosa das paredes do cálice e do pilar apresentou capacidade resistente superior ao modelo com conformação lisa. Ambos, porém tiveram desempenho inferior ao bloco monolítico, com valores de $66 \%$ e $36 \%$ respectivamente.

Palavras-chave: blocos sobre duas estacas, concreto armado, fundações.

CMEC, UFG, SRocha Consultoria e Projetos Ltda, Goiânia, GO, Brasil,

Universidade Federal de Uberlândia, Faculdade de Engenharia Civil, Uberlândia, MG, Brasil;

Universidade Federal de Goiás, Regional Catalão, Faculdade de Engenharia, Catalão, GO, Brasil.

Received: 15 Oct 2015 • Accepted: 04 Mar 2016 • Available Online: 21 Nov 2016 


\section{Introduction}

\subsection{Initial considerations}

The foundations are element to connections the superstructures and the soil and it is responsible in to transfer the actions in the structures. The foundations are separates in two groups: the superficial foundations and deep foundations. The distinction between types are done about criteria the transmission the forces. In deep foundations the rupture not reaches the superficial layer of the soil. Usually, the rupture mechanism shown in the NBR 6122:2010 [1], reaches twice the small dimension of the foundations, so, the deep foundations are that in the your base of the foundation, are built with depth superior the three times the small dimension or superior the three meters.

The choice of the foundation for each building depends on several factors, such as construction technology available in the building area, economic conditions, geotechnical characteristics, intensity of actions, neighboring buildings, among others. With these factors and combinations of them, the engineer determines which type of foundation suitable for every situation.

Through studies on the choice of the type of foundation to be used in a particular construction, when the foundation is with piles, the construction of another structural element it is necessary: the pile caps. These pile caps are volume structures that have the function of solidarity heads of the piles and transfer the actions of the column to the piles.

Despite the importance of the pile cap, it does not allowed visual inspection when in service. Therefore, it is important to know their behavior. The models of design to this type of element are the strut and tie models and three-dimensional models.

The plan dimensions of the pile caps depend on the position of the piles, by adopting, in general, the smallest possible spacing between them to avoid the need to use suspension reinforced. This spacing is assumed equal to 2.5 times its diameter in the case of precast piles and 3.0 times the diameter if the piles are molded in place. When stabs the minimum distances between the piles, it avoids the group effect on the pile caps. It still must be a minimum distance between the faces of the pile and the end of the pile cap, in order to improve the conditions of the anchor of tie reinforced, as MUNHOZ [2].
The structural behavior and design depend on the rigidity of the pile cap, using the same criteria superficial foundation, according to ABNT NBR 6118: 2014 [3]. In the case of rigid pile caps can be adopted for the design and details of the pile caps, linear three dimensional structural models or nonlinear and strut and tie models, these being preferred latter for defining with better efficiency distribution of forces within the pile cap. The NBR 6118: 2014 [3] does not bring in your text recommendations for verification and design of this element only suggests that the criteria to be used and recommendations of the stress values in inferior (near the pile) and superior node (near the column). However, there are no recommendations determining the geometric shape of the strut.

Using model strut and tie, it is considered that the formation of discrete regions (known as $\mathrm{D}$ regions) that are the regions where the stress distribution is not linear and that are not valid hypotheses Bernoulli (known as regions $B$, where there linear change in tension acting on the cross section). In this model, the checks of the compression stress of the strut are from the model Blévot \& Frémy [4]. The stresses in the nodes zone, are suggested by NBR 6118: 2014 [3] and have lower values the stresses limits suggested by Blévot \& Frémy [4], considering the deleterious effect of tensile stresses in the node zone with traction. However, near the nodal zones without traction, that is, node with stress compression only, the NBR 6118:2014 [3] does not consider the effect of concrete triaxial compressive stress, reducing the value in the node zone equal to $0,58 \mathrm{n} f_{c d}$ (or $0,27 \mathrm{n} \alpha_{v} \mathrm{n} f_{c d}$ ) in function of the Rüsch effect, in the effect of increased concrete strength with the time, in the factor form and in the difference between the test of specimens and the behavior of the structure. The Model Code CEB-FIP [5] suggests geometries for the nodes of nodal regions, being possible to verify the stress in theses nodes.

The strut and tie model can be used considering in the flow of the stress in structure, using the minimal path forces, suggested by Schlaich et al. [6]. These stresses can be obtained through linear or no-linear analysis, using numeric methods, for example, the Finite Element Method.

The used the precast structures, it is necessary, after the construction of the pile and the pile caps, the setting of the column. After that, is necessary to ensure the fix of the column with the foundation. Then used a connecting element (The link between the pillar

\section{Figure 1 - Geometric properties of the monolith pile caps}

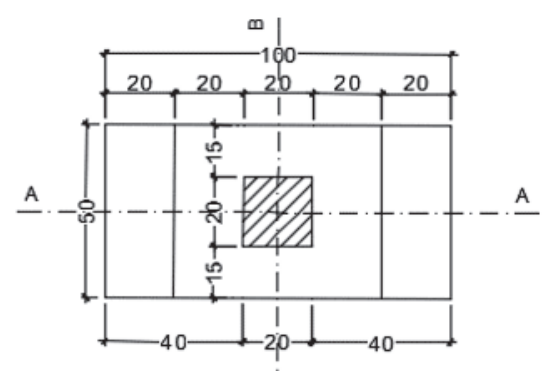

$\infty$

PLAN

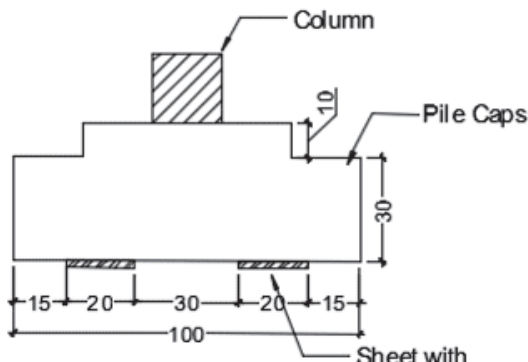

CUT AA

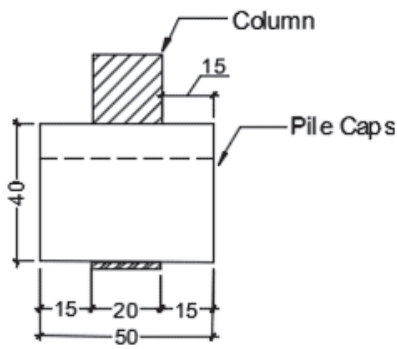

CUT BB 


\section{Figure 2 - Geometric properties of the rough connection pile caps of wall of the cup and the column}

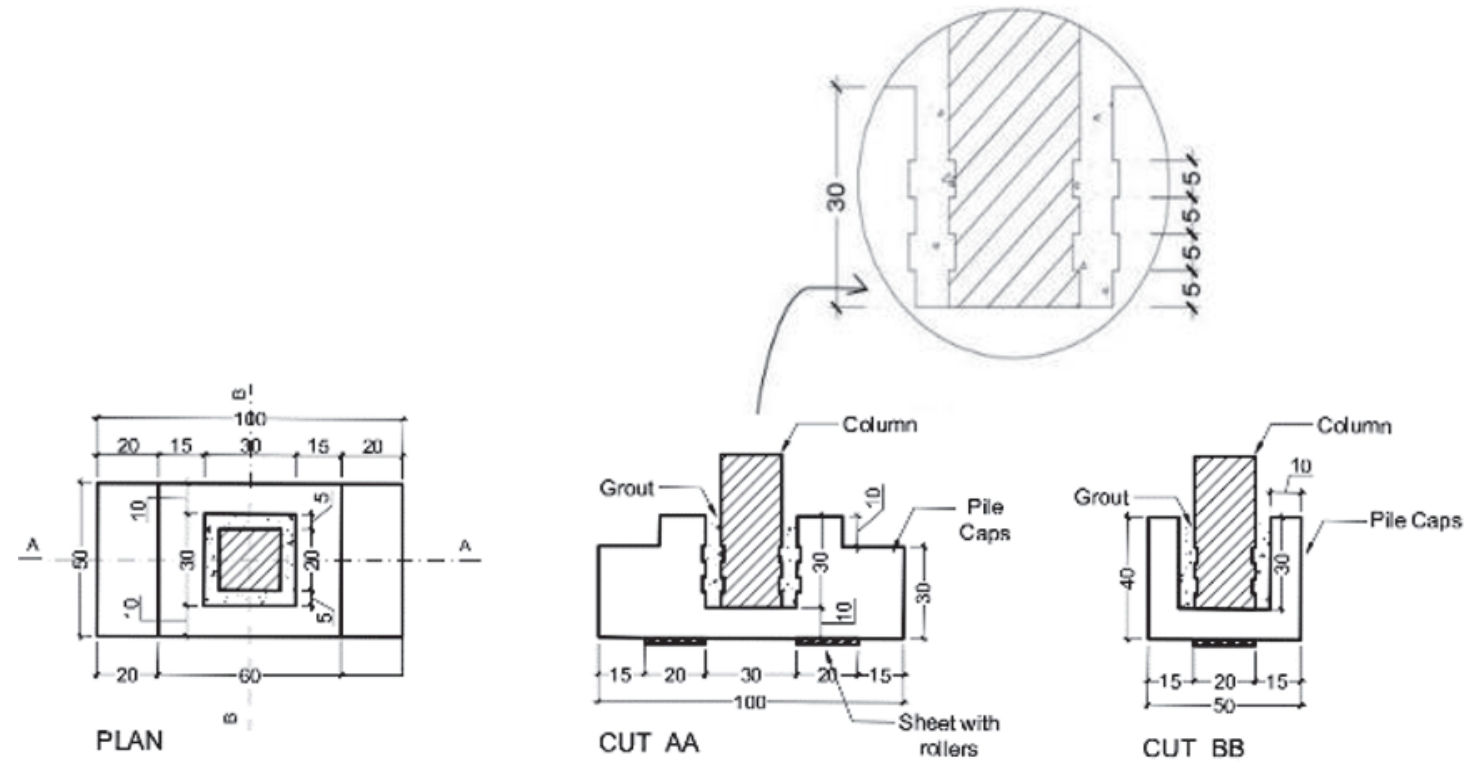

and the pile cap may occur through the base plate, by amendment of reinforcing steel bars with grout and hem, by amendment of protruding reinforcement bars and socket, which will be studied in this work), whose main objective structural transfer of efforts between the pillar and pile cap, and allow the structural interaction between them. These connections are discontinuous regions where stress concentrations occur and form a fine point with respect to the dimensioning and assembly of precast concrete structures, because they have great influence on the structural behavior of the same. The union of the superstructure through socket, in the pile cap is accomplished by embedding a part of column (embedded length) in an opening of the foundation element that enables its holder. Usually the socket is built on the block, but is also used pile caps with embedded or partially embedded socket.

\subsection{Objetivos}

The objective of this study is to analyze and discuss the structural behavior of the connection column-pile cap through of type socket in two pile caps, using experimental tests.

\section{Experimental program, materials and methods}

\subsection{Geometric properties of te models}

To this work, were buildings three models of the pile caps, one monolithic (column and pile caps concreted together - figure [1]), with reference models and two pile caps for precast column. One model for precast column has a socket-column interface with a rough surface (Figure [2]) and the other has socket-column interface with a smooth surface (Figure [3]).

As suggested by EL DEBS [7], the wall of the cup (hc) should be the greater of $10 \mathrm{~cm}$ and a third of the opening of the socket socket ( $\frac{h x_{i n t}}{3}$ and $\left.\frac{h y_{i n t}}{3}\right)$. Thus, the adopted value was equal to 10 centimeters (Figure [4]).

The distance between the support of the piles was defined to the angle of the strut in the relation in the horizontal plane was equal $\alpha$ $=60,23^{\circ}$. This value is below the allowed limit by NBR 6118: 2014 [3], those angle is equal to $63,43^{\circ}$. Thus, the distance between the centers of the support of the pile was adopted equal to $50 \mathrm{~cm}$.

It was necessary this distance depending on the space limitations for the use of testing equipment within the laboratory.

The embedded length $\left(l_{e m b}\right)$, defined by NBR 9062: 2006 [8], for precast columns with rough walls, is 40 centimeters. The roughness must be equal to 1 centimeter to 10 centimeters. However, by design criterion, it adopted the embedded length $\left(l_{\text {emb }}\right)$ of $30 \mathrm{~cm}$ and the roughness of 5 centimeters to 10 centime-

ters. These values were adopted by the ease of construction of this surface in the industry or in place, using wood slats found commercially, with dimensions of 5:01 cm. Although the embedded length be less than that specified by NBR 9062: 2006 [8], it is according to the EN 1991 [9], given by $1,2 h_{x}$ or $1,2 h_{y}$, being $h_{x}$ and $h_{y}$ defined as the dimensions of the abutment.

Another item recommended by NBR 9062: 2006 [8] for determining the embedded length of column, refers to the length required for bond of reinforcing steel bars abutment for transferring stress to the pile cap. This length of embedded inlay must be greater than the length of bond. In this case, it was considering the diameter of the longitudinal steel bars equal the sixteen millimeter, type CA-50, conditions of the good bond and average compressive strength equal the $48 \mathrm{MPa}$, the value this length will be 18,4 centimeters. 


\section{Figure 3 - Geometric properties of the smooth connection pile caps of wall of the cup and the column}

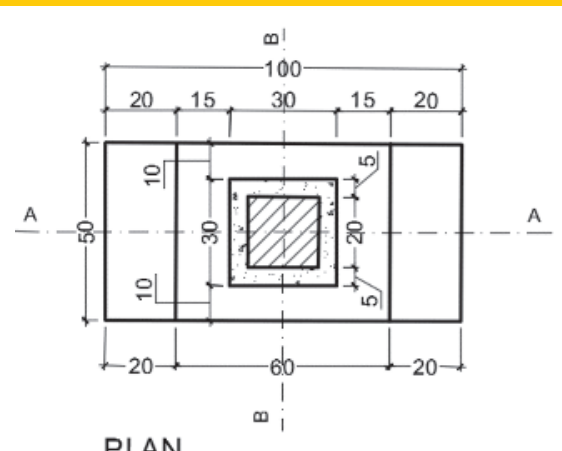

PLAN

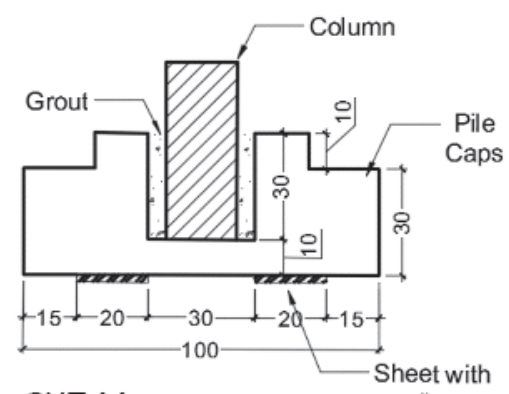

CUT AA

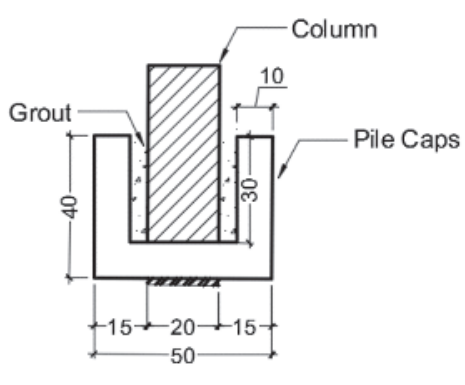

CUT BB
The ABNT 6118:2014 [3] indicated the favorable effect of the strut near the column (describe in the item 9.4.2.5 and 22.7.4.14), in function the concentration of the stress compression in this region, may be applied the redactor coefficient to length bond, that by Fusco [10] is equal the 0,60 , what resulted the eleven centimeters.

\subsection{Concrete}

The construction of the pile caps was made with Self-compacting concrete. This concrete it was produced in the CMEC Structures Laboratory (Master course in Civil Engineering - UFG). The used this concrete justified by researches realized by CMEC about Selfcompacting concrete. The materials to construction were donated by Redmix Concrete Brazil Inc. The characterization of materials and the study of concrete mix design they were made by Carlos Campos Laboratory Consulting and Design Ltd.

The mix of concrete used in the construction of the pile caps it was equal a $1: 2,05: 1.36 ; 1.14 ; 0,76: 0,67$ (cement, natural sand, artificial sand, rock 0 , rock 1 and water-cement ratio $-\mathrm{a} / \mathrm{c}$ ). To achieve the required fluidity and cohesion were also used $0.6 \%$ of polyfunctional additive, the superplasticizer $0,4 \%$ and $6 \%$ active silica, both in relation to the Cement consumption.
The mechanics properties of concrete were obtained by test cylindrical specimens compressive, tensile strength by diametrical compression and elasticity module.

The average compressive strength and tensile concrete used in the molding pile caps, at 28 days, had values equal to $44,5 \mathrm{MPa}$ and 4,04 MPa respectively. The elasticity module to 31,2 GPa.

For the column was used grout industrial type Bautech brand with average compressive strength and superior traction of the pile caps with values equal to $48,0 \mathrm{MPa}$ and $4,2 \mathrm{MPa}$. The measured elasticity module was equal to $22,0 \mathrm{GPa}$.

The structural elements were built separately: first the pile caps, after the column, with your respective concretes.

After concrete curing and remove of the modes, the precast columns were placed in your respective pile caps and after to put grout in the socket.

\subsection{Reinforcement}

The steel bars used for reinforcement of the assembly were the Gerdau brand, donated by Prémoldaço Industry Precast Ltd. and assembled in the laboratory of CMEC structures (Master course in Civil Engineering - UFG).

\section{Figure 4 - Pile caps}
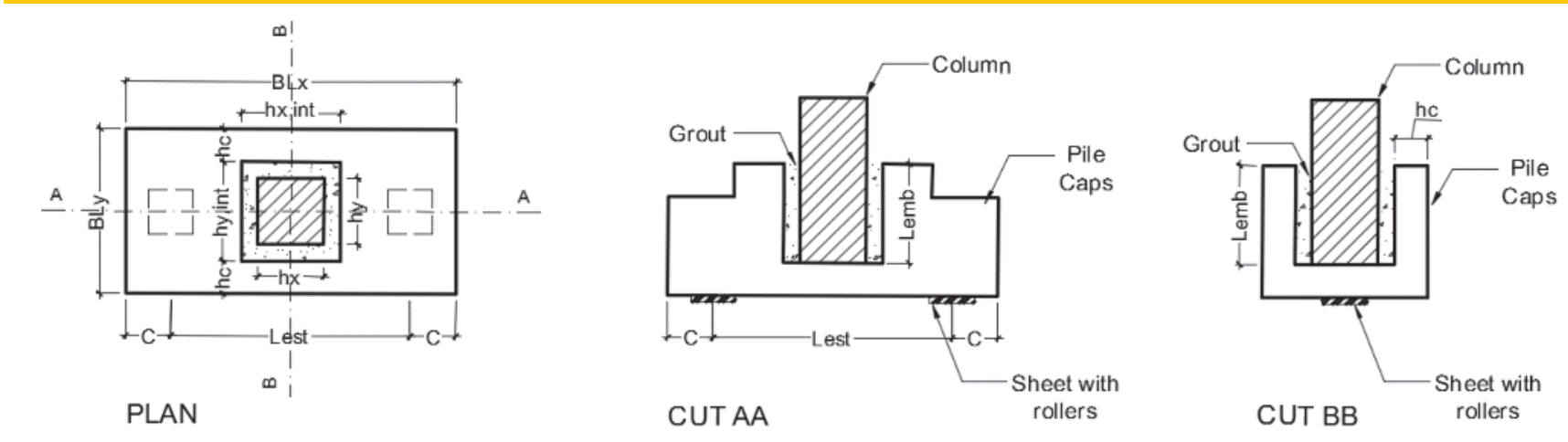


\section{Figure 5 - Schematic arrangement of the monolith pile caps}

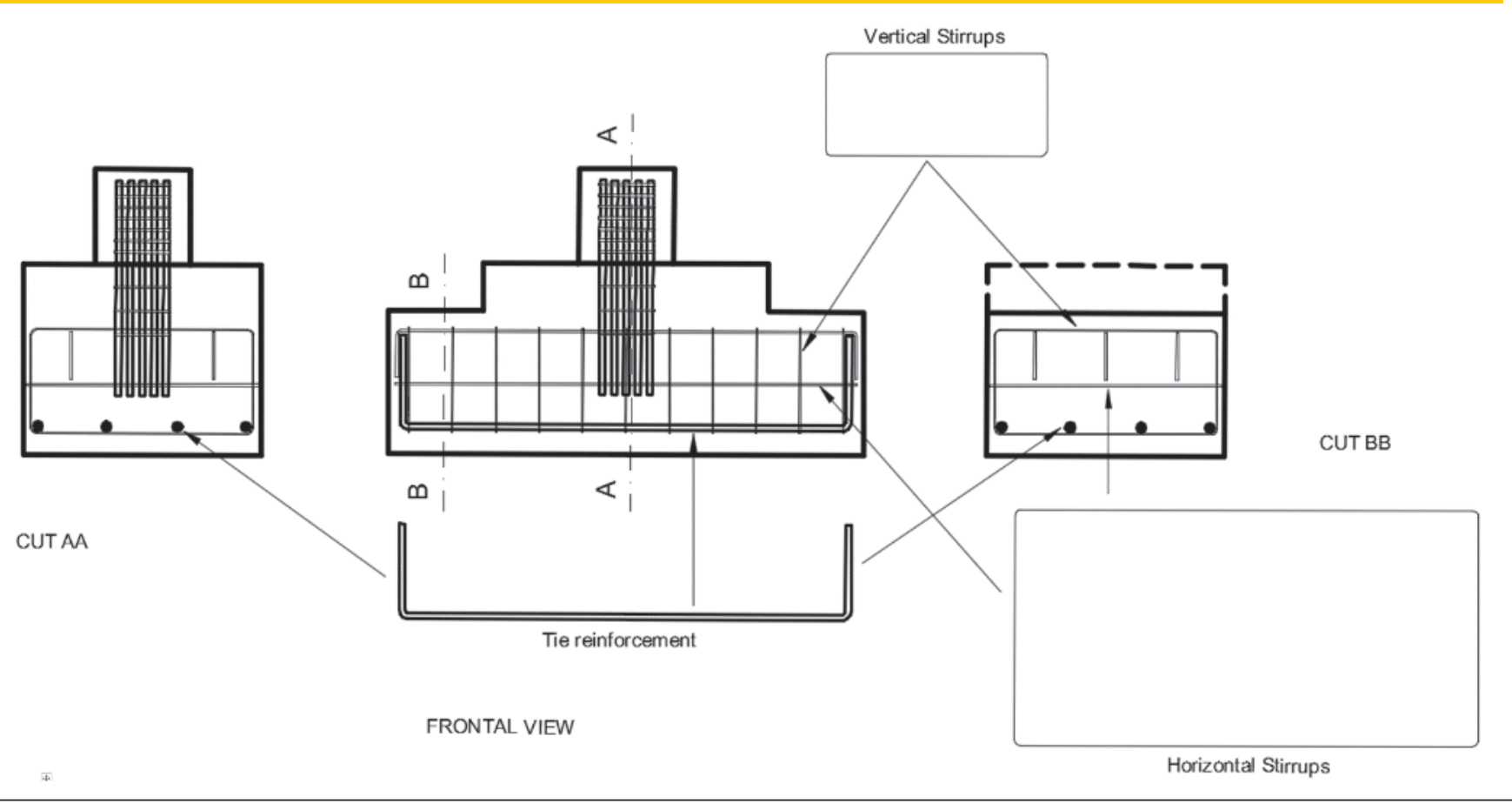

The pile caps were detailing with four steel bars of 16 millimeters and steel CA-50 to tie reinforcement; the horizontals and verticals stirrups with diameters equal to 6,3 millimeters, with spacing be- tween them equal to 10 centimeters. The Figure [5] to show the reinforcement used in monolithic pile cap and the Figure [6] the reinforcement of the precast models.

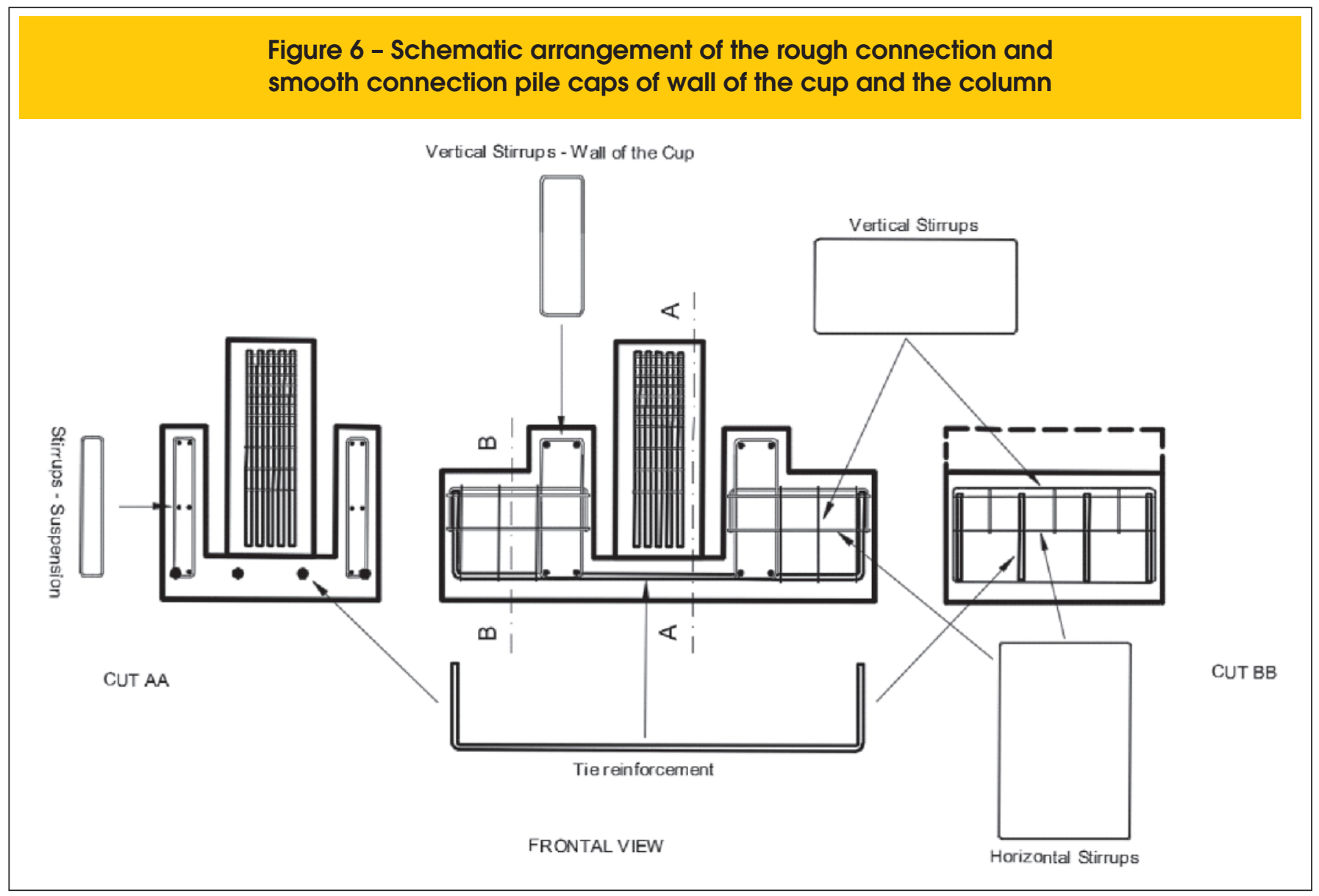


Figure 7 - Position of electrical-resistance strain gages and dial indicators in the pile caps

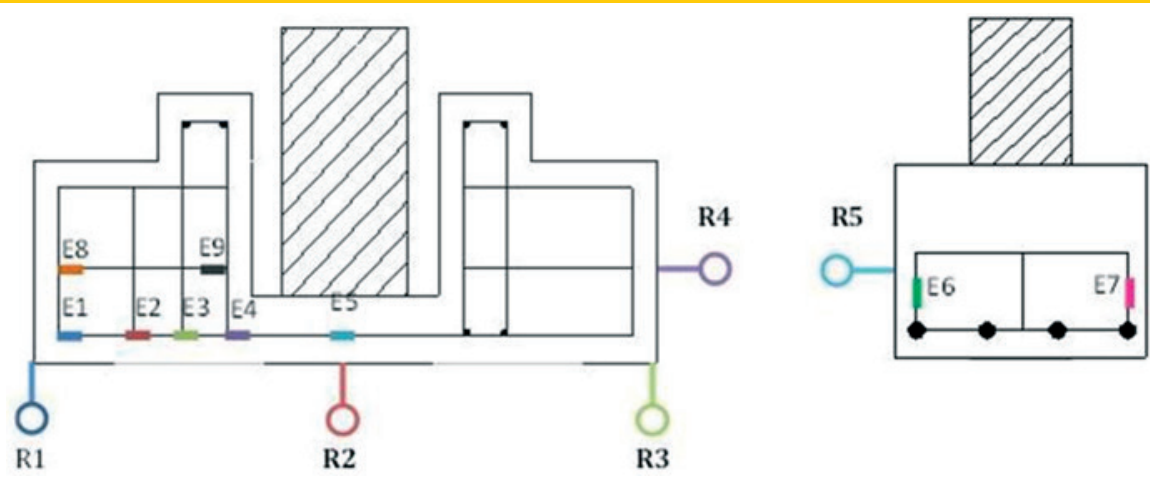

The average yield stress $\left(f_{\mathrm{yk}}\right)$ of the steel bars with 16 millimeters were equal a $559 \mathrm{MPa}$ and yield strain $\left(\varepsilon_{\mathrm{y}}\right)$ was equal the $3,46 \%$. To steel bars with 6,3 millimeters, the value of the yield strain was equal the $2,77 \%$ and the yield stress equal the $523 \mathrm{MPa}$.

\subsection{Molds}

The molds to construction of the pile caps and columns were made with wooden plate plasticized plywood with thick of the $18 \mathrm{~mm}$, in the CMEC Structures Laboratory.

For the construction of the rough surface in the model with roughening of the socket and column, were put pieces of the Styrofoam with a thickness of 1,0 centimeters. Also were placed piece of the Styrofoam in the interface pile/pile cap, for subsequent fitting of plate metal. These plates metals, which were supported on rollers, were thickness of 20,0 millimeters.

\subsection{Instrumentation}

The deformations of the tie, the stirrups were analyzed by straingages of 5 millimeters of the base, trade maker Sensors Excel Ltd. The displacement horizontal and vertical of pile caps were obtained by five dial gages.

The Figure [7] to show the positions were installed the strain-gages and the dial gages.

\subsection{Experimental analysis}

The experimental tests were realized in Materials and Structures Laboratory of Goias University, using hydraulic machine, with capacitated of $3.000 \mathrm{kN}$ and length piston equal to 1 meter. The loads were obtained by analogic dial of machine.

To simulate the pile of pile caps, were used two sets of metal plates, supported on rollers of metal. These sets served as support equipment for restricting the vertical displacement and allowing horizontal displacement.

The intention of rollers was simulate the rotation of piles in soil, after the loading of pile cap, by vertical and horizontal forces and bending, according with model to design.

The load was applied in the top of column, in steps of loads, divided every each $10 \mathrm{kN}$.

The Figure [9] shows the set of test.

\section{Results and discussions}

The monolithic specimens, to reference, showed greater load capacity, when comparted with the precast pile caps. The model precast pile cap, with the rough shaping of the walls of the socket and the column showed better performance than the model with the smooth conformation, but still below the monolithic model.

The rupture load of the monolithic pile caps was equal to $2150 \mathrm{kN}$ (Figure[10]), while the pile cap with roughened walls and column,

\section{Figure 8 - Detail of the sets of sheet metal supported on metal rollers to simulate the column}
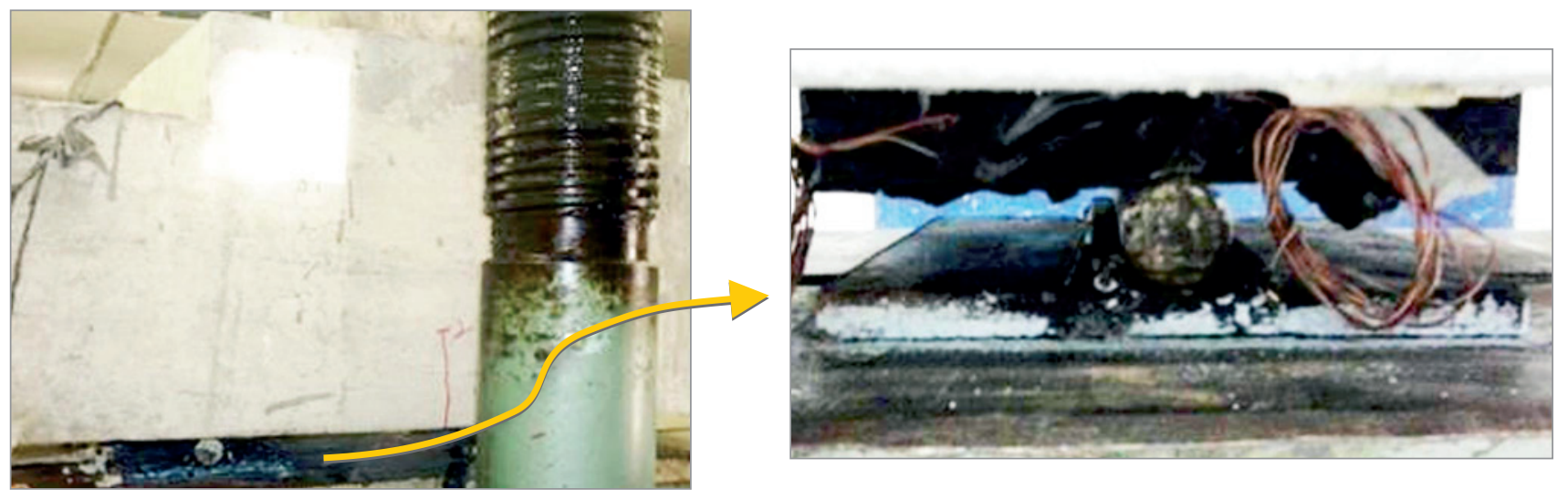
Figure 9 - Tests of two pile caps
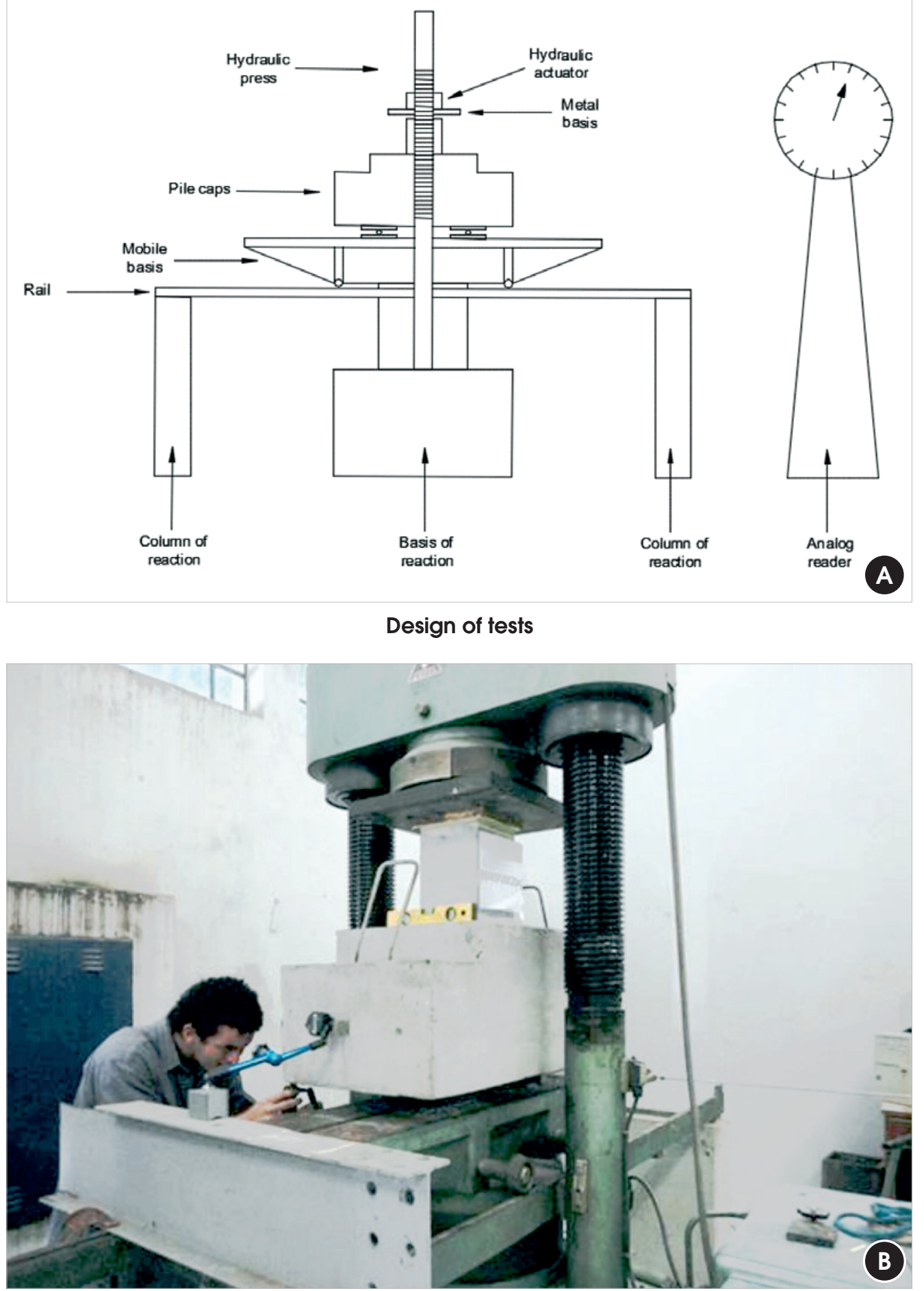

Illustrative picture of tests 
was load equal to $1420 \mathrm{kN}$ (Figure [11]), a corresponding performance at $66 \%$ compared to the monolithic model. But the pile caps with smooth conformation of the walls of the socket and the column, supported a load equal to $780 \mathrm{kN}$ (Figure [12]), obtaining performance of the $36 \%$ when compared to monolithic model.

Similarly the pile cap model with smooth conformation of the walls of the socket and the column, showed performance $55 \%$, when compared with rough pile cap.

The models of monolithic pile cap and precast pile caps with roughened walls, had collapsed by traction of strut, followed by concrete crushing. It was verified that the occurred yield of the steel bars.
The precast pile caps with smooth walls, to show rupture fragile, by punching shear in the background pile cap, near the piles (Figure [13]). This fact is explained by deficiency of bond between walls socket and column, what result that the load in the column was to the background of pile cap and not making the struts.

In the Table [1], showed the relation between the ultimate load of pile caps and a comparison was performed between the same, with reference to the monolithic pile cap.

The pile caps tested were design using the Blévot \& Frémy Model [4], considering that the struts between column and pile. The stresses in the nodal zone were verified by recommendations of the Bra-

\section{Figure 10 - Deformations in tie reinforcement bars strain - monolith pile caps: force of first crack and last force}
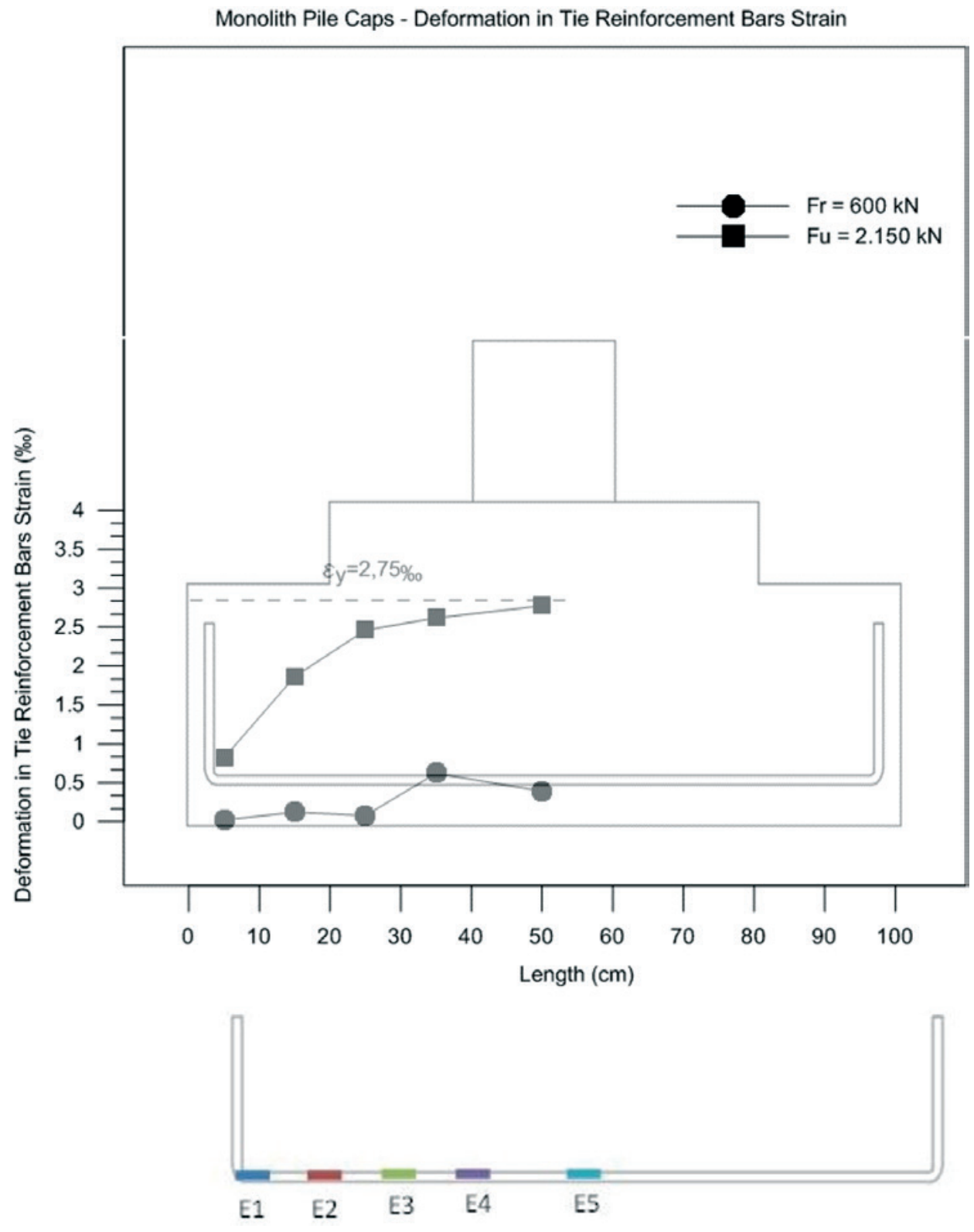
zilian Code - ABNT 6118:2014 [3].These analyzes are showed in the Table [2]. To design these stress, it not considered the increase coefficient of load and mitigation coefficients of the materials.

In the Table [3], it was made the relations between the values of effective stress in the limited stress. It was observed that the rupture of monolithic model occurred by diagonal traction of strut, followed of the crushing of strut and after the yield of the tie. (see Figure [10]). It was observed that the limited stress recommendations by Brazilian Code - ABNT 6118:2014 [3] are conservatives, because not was considered the behavior of the biaxial concrete in the superior nodal zone.
In the experimental tests of precast pile caps in this research, the Blévot \& Frémy Model [4] not showed adequate results. With reference to the monolithic model and stress limited established by Blévot \& Frémy [4], the NBR 6118: 2014 [3], and the rupture load for each model, it was determined the theoretical inclinations of the strut and their respective heights useful and compared with experimental results. The results are show by Table [4] and Figure [14].

The results showed in the Table [3], indicate that the experimental values, when compared with the theoretical values are fairly representative for the monolithic and rough models, when using the recommendations of Blévot \& Frémy [4]. When analyzing the

\section{Figure 11 - Deformations in tie reinforcement bars strain - rough connection pile caps: force of first crack and last force}

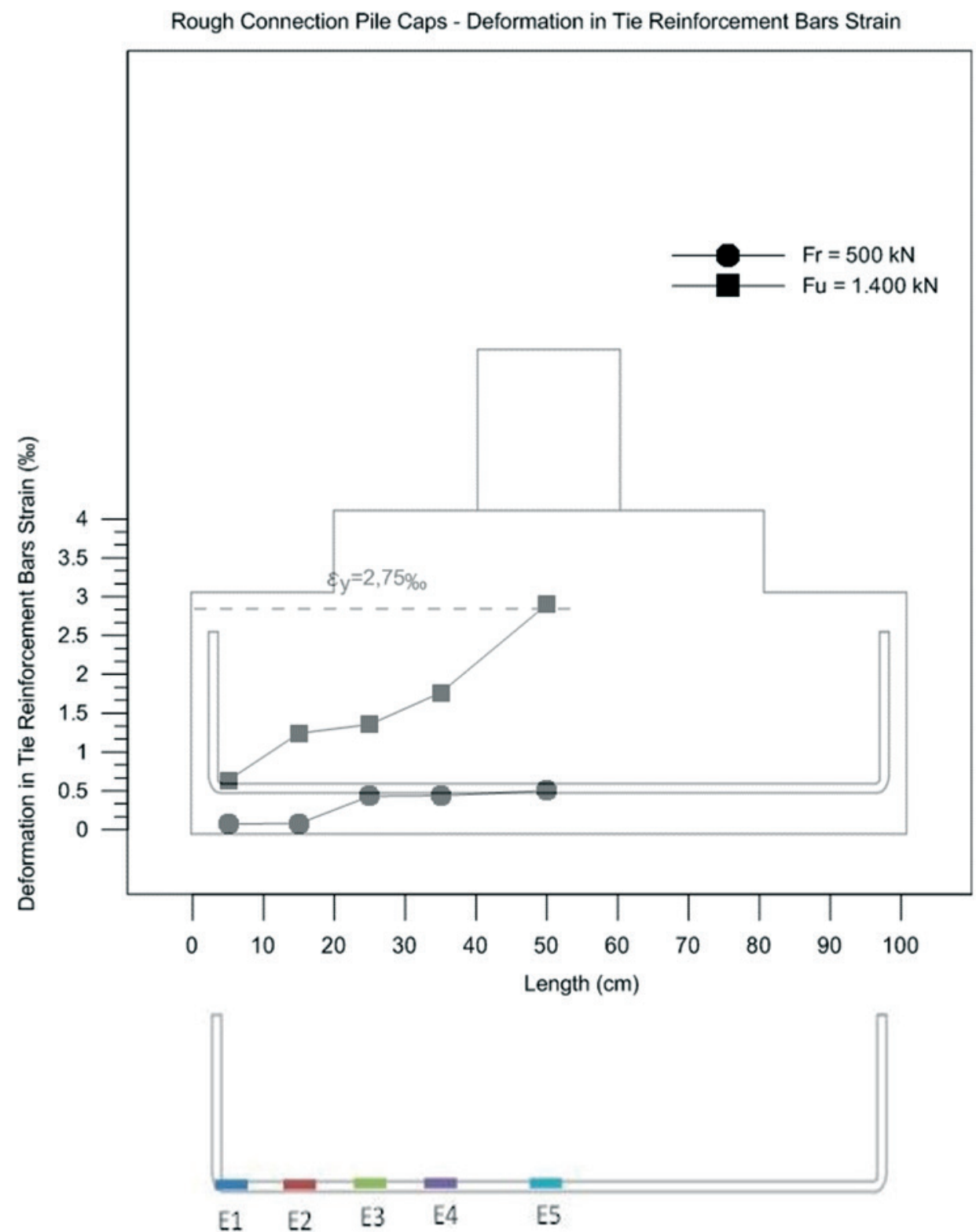


values obtained when used the criteria to NBR 6118: 2014 [3], it was found that the pile caps should have greater rigidity to be the conditions of nodal security.

With respect to the forces on the ties, there was a significant reduction when the steel bars of the tie through the inferior nodal zone near the pile. This reduction is caused by the favorable effect of the strut, which increases the frictional force at the interface of steel bars and concretes that region. Table [5] shows these results.

The results presented in Table [5], corroborate the results obtained by Adebar et al. [11] Miguel [12] \& Giongo Delalibera [13] Barros \& Giongo [14] and Delalibera \& Giongo [15].

\section{Conclusion}

The model monolith, taken as a reference, was as expected, due to the model to design used, based on Model Blévot \& Frémy [4], with rupture load of $2,150.00 \mathrm{kN}$. The rupture was due to the traction diagonal, followed by crushing of the strut concrete.

The model precast pile cap with rough of wall of the socket and column had underperformed the monolith model, with rupture load equal to $1420.00 \mathrm{kN}$. The ruptures occurred by diagonal traction of the strut, following by crushing of strut concrete and yield of the steel bars of the tie.

\section{Figure 12 - Deformations in tie reinforcement bars strain - smooth} connection pile caps: force of first crack and last force

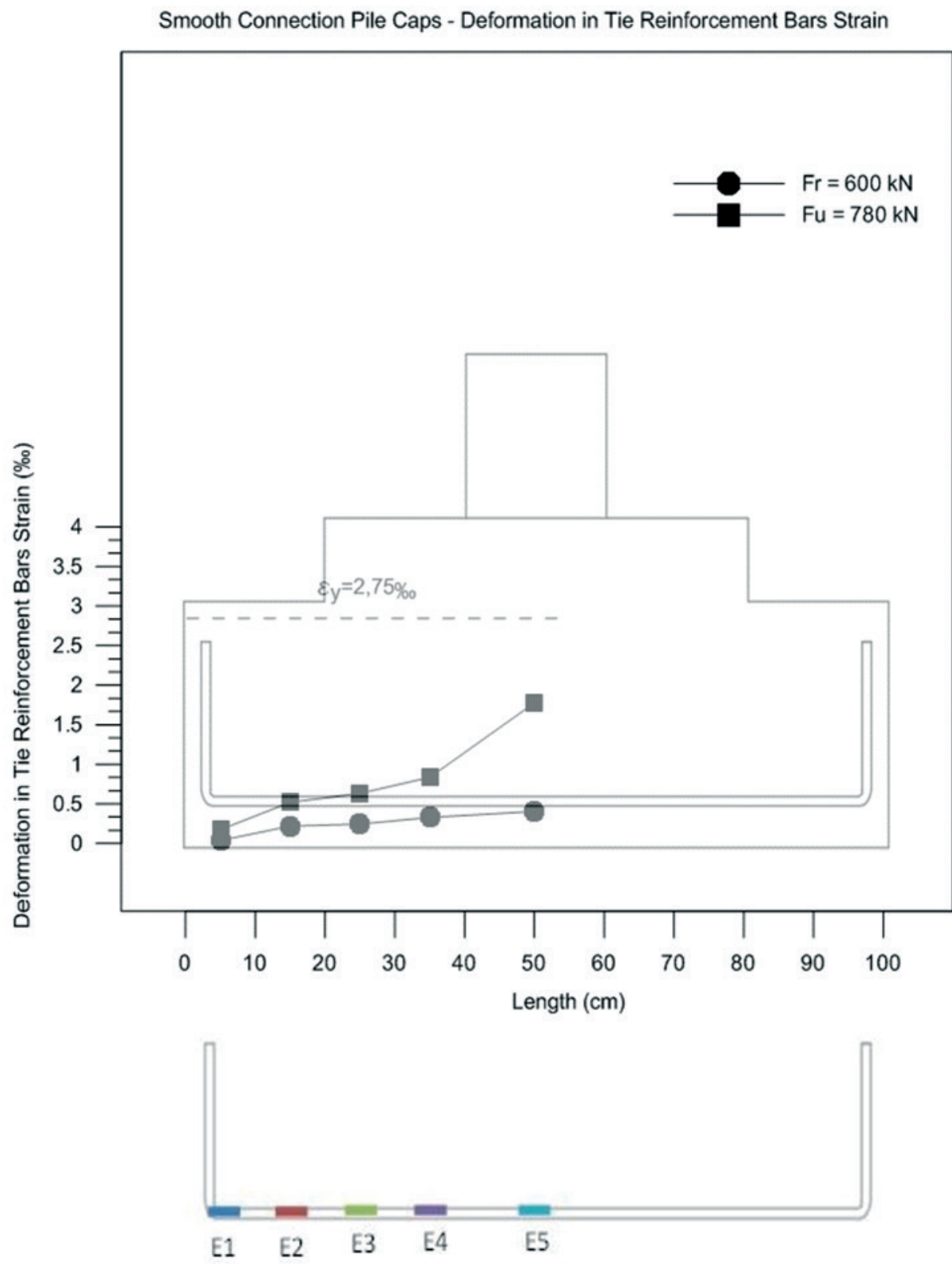


The model precast pile cap with smooth conformation of wall of the socket and column, had performance below the monolithic model. The rupture load was equal to $780 \mathrm{kN}$. The rupture occurred by punching of the background of the pile cap, near of piles. The steel bar of the tie has not shown yield, but occurred slip.

The transfer of the load of column to pile was efficient in the rough model. This indicates that the roughness of the socket and of column it worked as shear key, which allowed the formation of struts, a fact confirmed also by cracking mad of the tested model. For the pile caps with smooth conformation, the transfer of load of column to pile was inefficient, indicating the behavior of bending and shear. Due to the small length of inlay, the conformation smooth showed shear key, transferring the load directly to background of the pile cap. This fact caused punching, what can be observed by cracking map in Figure [14]. Another fact which confirms this conclusion is the theoretical value calculated to inclination of strut, depending on the rupture load, generating a lower value than recommended by Blévot \& Frémy [4], as shown in Table [4].

It was found that the strength of the strut decreases the tensile force in the tie, due to the increased friction in the inferior nodal region.

The models of the monolithic pile cap and precast pile caps with the roughened conformation of the walls of the socket and the column showed characteristic behaviors of rigid pile cap, as determined by NBR 6118: 2014 [3]: the existence of the concrete compression struts, diagonal cracks of column going to the pile

\section{Figure 13 - Curve load vs. displacement}

\section{Comparative Graph: Applied Load in Column X Horizontal Displacement Between Pile Caps} Dial Indicators R2

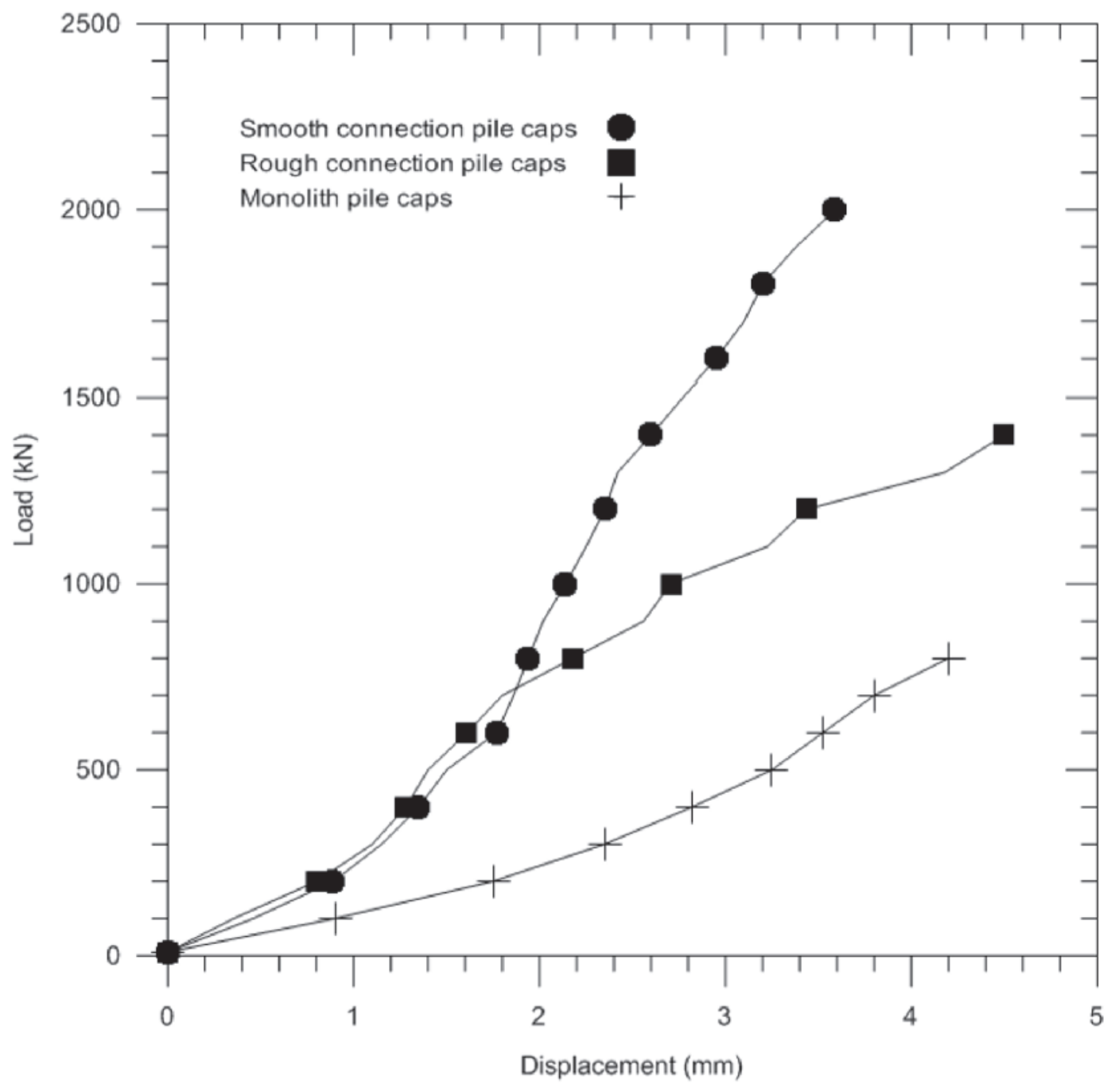




\section{Table 1 - Load rupture of pile caps tested}

\begin{tabular}{ccc}
\hline Pile caps & $F_{u}(\mathrm{kN})$ & $F_{u, \text { Monolitioco }} / F_{u}$ \\
\hline $\begin{array}{c}\text { Monolith } \\
\text { Rough }\end{array}$ & 2150 & 1 \\
$\begin{array}{c}\text { Smooth } \\
\text { connection }\end{array}$ & 1420 & 1,51 \\
\hline
\end{tabular}

and flexion-compression on the piles.

But the model of the precast pile cap with the smooth conformation of the walls of the socket and the column showed similar behavior to flexible pile caps. Thus, it is evident that when using this type of conformation should work with larger inlays lengths, thus avoiding the fragile collapse, by puncturing the model.

\section{Acknowledgements}

To: Higher Education Personnel Improvement Coordination CAPES for the financial support to perform the research that made it possible to write this paper.

To: Redimix Concrete Brazil S.A. for the supply of materials for molding the concrete used.

To Laboratory Carlos Campos Consultancy and Projects Ltd for the characterization of materials and the concrete dosage study. At Prémoldaço Industry Precast Ltd for the supply of steel bars used.

\section{Table 2 - Strain in the superior and inferior nodal zone}

\begin{tabular}{|c|c|c|c|c|c|c|}
\hline Pile caps & $\begin{array}{c}\sigma_{\mathrm{b}, \text { estaca }} \\
\left(\mathrm{kN} / \mathrm{cm}^{2}\right)\end{array}$ & $\begin{array}{c}\sigma_{\text {b,pilar }} \\
\left(k N / \mathrm{cm}^{2}\right)\end{array}$ & $\begin{array}{c}\sigma_{\text {lim,estaca,Blévot }} \\
\left(\mathrm{kN} / \mathrm{cm}^{2}\right)\end{array}$ & $\begin{array}{l}\sigma_{\text {lim,estaca,NBR }} \\
\left(\mathrm{kN} / \mathrm{cm}^{2}\right)\end{array}$ & $\begin{array}{l}\sigma_{\text {lim,pilar,Blévot }} \\
\left(\mathrm{kN} / \mathrm{cm}^{2}\right)\end{array}$ & $\begin{array}{l}\sigma_{\text {lim,pilar,NBR }} \\
\left(\mathrm{kN} / \mathrm{cm}^{2}\right)\end{array}$ \\
\hline Monolith & 3,36 & 6,72 & 4,45 & 2,20 & 6,23 & 3,11 \\
\hline $\begin{array}{c}\text { Rough } \\
\text { connection }\end{array}$ & 2,22 & 4,44 & 4,45 & 2,20 & 6,23 & 3,11 \\
\hline $\begin{array}{c}\text { Smooth } \\
\text { connection }\end{array}$ & 1,22 & 2,44 & 4,45 & 2,20 & 6,23 & 3,11 \\
\hline \multicolumn{7}{|c|}{ 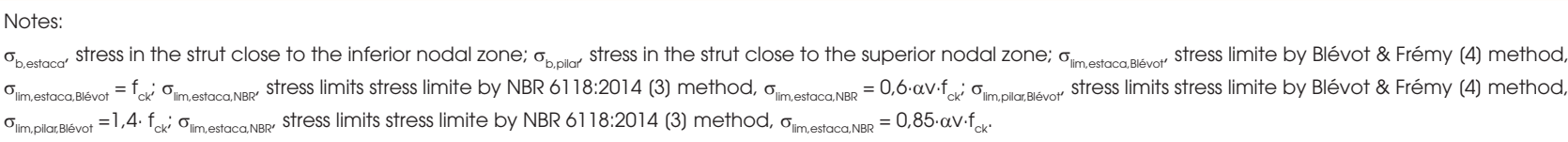 } \\
\hline
\end{tabular}

\section{Table 3 - Ratio betweem in the nodal zone}

\begin{tabular}{|c|c|c|c|c|}
\hline Pile caps & $\sigma_{\mathrm{b}, \text { estaca }} / \sigma_{\text {lim,estaca,Blévot }}$ & $\sigma_{b, p i l a r} / \sigma_{\text {lim,pilar,Blévot }}$ & $\sigma_{\mathrm{b}, \text { estaca }} / \sigma_{\text {lim,estaca,NBR }}$ & $\sigma_{\text {bpilar }} / \sigma_{\text {lim,pilar,NBR }}$ \\
\hline Monolith & 0,76 & 1,08 & 1,53 & 2,16 \\
\hline $\begin{array}{c}\text { Rough } \\
\text { connection }\end{array}$ & 0,50 & 0,71 & 1,00 & 1,43 \\
\hline $\begin{array}{c}\text { Smooth } \\
\text { connection }\end{array}$ & 0,27 & 0,39 & 0,55 & 0,78 \\
\hline
\end{tabular}

\section{Table 4 - Inclination of the strut, in function of the forces}

\begin{tabular}{|c|c|c|c|c|c|c|}
\hline Pile caps & $\theta_{\text {Blévot }}\left({ }^{\circ}\right)$ & $\theta_{\text {NBR 6118:2014 }}\left({ }^{\circ}\right)$ & $\mathrm{h}_{\text {Blévot }}(\mathrm{cm})$ & $\mathrm{h}_{\mathrm{NBR}}(\mathrm{cm})$ & $\theta_{\text {Exper }}\left({ }^{\circ}\right)$ & $\mathrm{h}_{\text {Exper }}(\mathrm{cm})$ \\
\hline Monolith & 60,23 & 60,23 & 40,00 & 40,00 & 47,00 & 39,00 \\
\hline $\begin{array}{c}\text { Rough } \\
\text { connection }\end{array}$ & 39,17 & 64,07 & 21,30 & 46,13 & 42,00 & 25,86 \\
\hline $\begin{array}{c}\text { Smooth } \\
\text { connection }\end{array}$ & 27,91 & 52,36 & 15,60 & 22,90 & - & 9,80 \\
\hline
\end{tabular}




\section{Figure 14 - Pile caps tested - identification of angle of inclination of the struts}

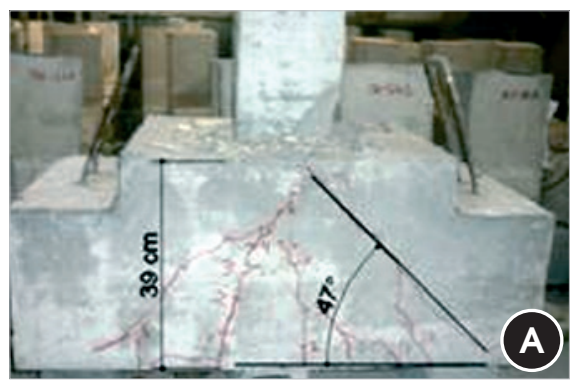

Monolith pile caps

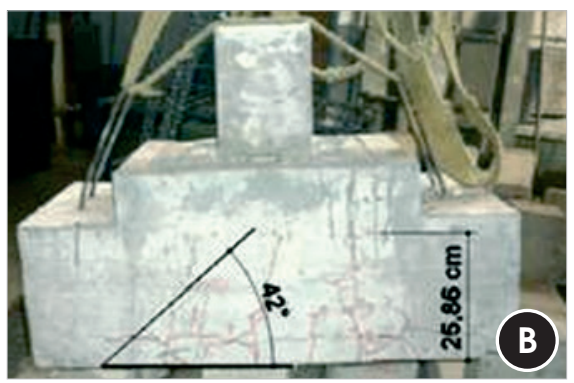

Rough connection pile caps

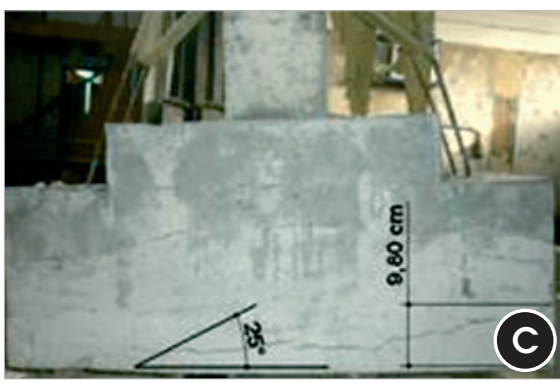

Smooth connection pile caps

\section{Bibliographical references}

[1] ASSOCIAÇÃO BRASILEIRA DE NORMAS TÉCNICAS. ABNT NBR 6122:2010 - Projeto e execução de fundações.

Rio de Janeiro, 2014.

[2] MUNHOZ, F.S. (2004). Análise do comportamento de blocos de concreto armado sobre estacas submetidos à ação de força centrada. Dissertação (mestrado) - Escola de Engenharia de São Carlos, Universidade de São Paulo, São Carlos.

[3] ASSOCIAÇÃO BRASILEIRA DE NORMAS TÉCNICAS. ABNT NBR 6118:2014 - Projeto de estruturas de concreto. Rio de Janeiro, 2014.

[4] BLÉVOT, J.; FRÉMY, R. (1967). Semelles sur piex. Analles d'Institut Techique du Bâtiment et des Travaux Publics, Paris, v. 20, n. 230.

[5] COMITE EURO-INTERNACIONAL DU BÉTON (1990). CEB-FIP Model code for concrete structures. Bulletin D'Information, Paris, n. 203-205, July.

[6] SCHLAICH, J.; SCHAFER, K.; JENNEWEIN, M. (1987). Toward a consistente design of reinforced structural concrete. Journal of Prestressed Concrete Institute, v. 32, n. 3, May-June;

[7] EL DEBS, M. K.; Concreto pré-moldado: fundamentos e aplicações. $1^{\text {a }}$ ed. São Carlos, SP, Publicações EESC-USP, 2000.

[8] ASSOCIAÇÃO BRASILEIRA DE NORMAS TÉCNICAS. ABNT NBR 9062:2006 - Projeto e execução de estruturas de concreto pré-moldado. Rio de Janeiro, 2007.
[9] EN 1991-1-1. Eurocode 2: Design of concrete structures Part 1-1: General rules and rules for buildings. European standard, 2004.

[10] FUSCO, P. B. (1994). Técnicas de armar estruturas de concreto. Editora Pini Ltda., São Paulo.

[11] ADEBAR, P.; KUCHMA, D.; COLLINS, M. P. (1990). Strutand-tie models for design of pile caps: an experimental study. ACl Journal, v. 87, p. 81-91, Jan/Feb;

[12] MIGUEL, G. M. (2000). Análise experimental e numérica de blocos sobre três estacas. Tese (doutorado) - Escola de Engenharia de São Carlos, Universidade de São Paulo, São Carlos;

[13] DELALIBERA, R. G.; GIONGO, J. S.. Deformation in the strut of two pile caps. IBRACON Structural an Material Journal, v.1, n.2, p. 121-157, june, 2008.

[14] BARROS, R.; GIONGO, J. S.. Estudo experimental de blocos de fundação com cálice externo, embutido e parcialmente embutido considerando interface lisa. IBRACON Structural an Material Journal, v.6, n.5, p. 737-764, October, 2013.

[15] DELALIBERA, R. G.; GIONGO, J. S.. Numerical analysis of two pile caps with sockets embedded, suject the eccentric compression load. IBRACON Structural an Material Journal, v.6, n.3, p. 436-474, june, 2013.

Table 5 - Forces on tie reinforcement bars strain

\begin{tabular}{|c|c|c|c|c|c|c|}
\hline Pile caps & $\mathbf{R}_{\text {sty }}(\mathbf{k N})$ & $\mathrm{R}_{\mathrm{st}, 5}(\mathrm{kN})$ & $\mathbf{R}_{\mathrm{st}, 3}(\mathbf{k N})$ & $\mathbf{R}_{\text {sty }} / \mathbf{R}_{\text {st }, 5}$ & $\mathbf{R}_{\mathrm{st} 3} / \mathbf{R}_{\mathrm{st}, 5}$ & Condition \\
\hline Monolith & 449,57 & 346,93 & 238,30 & 1,89 & 0,69 & Not yield \\
\hline $\begin{array}{c}\text { Rough } \\
\text { connection }\end{array}$ & 449,57 & 449,57 & 162,42 & 1,0 & 0,36 & Yield \\
\hline $\begin{array}{l}\text { Smooth } \\
\text { connection }\end{array}$ & 449,7 & 217,00 & 42,88 & 2,07 & 0,20 & Not yield \\
\hline
\end{tabular}

